УДК 17.03

\author{
Kunderevich Elena, \\ Candidate of Philosophy, Associate Professor, \\ Associate Professor of the Department of Philosophy \\ Kyiv National University of Culture and Arts \\ 1.kunderevich@gmail.com \\ orcid.org/ 0000-0001-7248-5033
}

\title{
INFORMATION AND COMMUNICATION MECHANISMS OF THE INFLUENCE ON SOCIAL CONNECTION: AXIOLOGICAL ASPECT
}

Purpose of Research. The purposes of the research are to analyse the information and communication mechanisms of the influence on social consciousness, to consider the role of numerical taboos, which can be understood as a manifestation of social and communicative pathology or a kind of special «information illness» of the society. Methodology. The methodology of the article includes the general scientific and special methods of the research such as analysis, synthesis, logical method and the method of generalization. Scientific Novelty. The scientific novelty of the article consists of the proposed ways to block the implicit taboos, to reveal their genetic roots such as a fear, in order to reduce the false impact on social consciousness. In addition, there is the substation of the possibility to overcome the inertia of the strategy of the confrontation in the process of formation of individual and social self-consciousness. Conclusions. All in all, the information immunity in the forms of various taboos, implanted "from above», will not be effective. The immune system of the organism as a whole is based on sufficiently effective self-correction of the protective and tolerant reactions. Thus, taking into account the administrative and legal aspects of the protection against such phenomena, we should hope for those protective barriers that are created by the «moral immunity» of the individual.

Key words: social consciousness, self-consciousness, information mechanisms of influence, information illness, information immunity, social communication, fear, moral nature, freedom.

Кундеревич Олена Вікторівна, кандидат філософських наук, доцент Київського національного університету культури і мистецтв

\section{ІНФОРМАЦІЙНО-КОМУНІКАЦІЙНІ МЕХАНІЗМИ ВПЛИВУ НА СУСПІЛЬНУ СВІДОМІСТЬ: ЦІННІСНИЙ АСПЕКТ}

\begin{abstract}
Метою роботи $\epsilon$ аналіз інформаційно-комунікаційних механізмів впливу на суспільну свідомість, розгляд ролі чисельних табу, щзо можуть розумітися як прояв соціально-комунікативної патології, своєрідної «інформаційної хвороби» суспільства. Методологія дослідження базується на застосуванні загальнонаукових та спеціальних методів пізнання, зокрема: аналізу, синтезу, логічного методу та методу узагальнень. Наукова новизна полягає у запропонуванні шляхів блокування неявних табу, виявлення їх генетичного коріння - страху, з метою зменшення хибного впливу на суспільну самосвідомість, обтрунтуванні можсливість подолання інериіі стратегії конфронтації в процесі становлення самосвідомості людини і соціуму. Висновки. Інформаційний імунітет у формі різних табу, що насаджуються "зверху», ніколи не буде в достатній мірі ефективним. Імунна система організму в иілому базується на достатньо ефективній самокорекиіі захисних та толерантних реакиій. Таким чином, не заперечуючи адміністративних та юридичних аспектів захисту від подібних явищ, потрібно все ж таки сподіватися на ті захисні бар'єри, щьо створюються саме «моральнісним імунітетом» особистості.
\end{abstract}

Ключові слова: суспільна свідомість, самосвідомість, інформаційні механізми впливу, інформаційна хвороба, інформаџійна імунність, соиіальна комунікація, страх, моральна природа, свобода. 


\section{Кундеревич Елена Викторовна, кандидат философских наук, доцент, доцент Киевского национального университета культуры и искусств}

\section{ИНФОРМАЦИОННО-КОММУНИКАЦИОННЫЕ МЕХАНИЗМЫ ВЛИЯНИЯ НА ОБЩЕСТВЕННОЕ СОЗНАНИЕ: ЦЕННОСТНЫЙ АСПЕКТ}

Целью работы является анализ информационно-коммуникационных механизмов воздействия на общественное сознание, рассмотрение роли многочисленных табу, которые понимаются как проявление сочииально-коммуникативной патологии, своеобразной «информационной болезни» общества. Методология исследования базируется на применении общенаучных и спещиальных методов познания, 8 частности: анализа, синтеза, логического метода и метода обобщений. Научная новизна заключается в предложении путей блокирования неявных табу, выявление их генетического корня - страха, с иелью уменьшения негативного воздействия на общественное самосознание, обосновании возможного преодоления инерциии стратегии конфронтации в прочессе становления самосознания человека и социума. Выводы. Информационный иммунитет в форме различных табу, насаждаемых «сверху», никогда не будет в достаточной мере эффективным. Иммунная система организма в изелом базируется на достаточно действенной самокоррекции защчтныхх и толерантных реакций. Таким образом, не отрицая административных и юридических аспектов защиты от подобных явлений, нужно все же надеяться на зашчитные барьеры, которые создаются «нравственным иммунитетом» личности.

Ключевые слова: общественное сознание, самосознание, информационные механизмы влияния, информачионная болезнь, информачионная иммунность, сочиальная коммуникаџия, страх, нравственная природа, свобода.

Actuality of Research. At the beginning of the XXI century, we can see the increasing of the interest in the analysis of the information and communication sphere. It is connected with a number of socio-political and ideological transformations. The problems of the modern social development are both at the level of technological development and at the level of the development of the scientific conceptions of the information, communication and moral sphere. Their analysis would give us an opportunity to formulate the conclusions and define the path of Ukraine to enter the world of information and social space.

In our opinion, the attempts to block the implicit taboos, to reveal their genetic roots such as a fear, in order to reduce the false impact on social consciousness, and to understand the role of the moral values in the individual and social transformations are very important.

Analysis of Researches and Publications. The problem of the interaction between an individual and a society as the dialectic of parasitism (E. Morin) and complementarity (N. Elias). The futuristic forecasts of D. Bell, A. Toffler, Z. Brzeziński about the qualitative re-socialization of society on the basis of information technologies, high level of innovation, knowledge management, growing individuality and de-standardization in the XXI century are being implemented rapidly. However, the reality of the information world has many contradictions both at the individual and social levels.

The purposes of the research are to analyse the information and communication mechanisms of the influence on social consciousness, to consider the role of numerical taboos, which can be understood as a manifestation of social and communicative pathology or a kind of special «information illness» of the society.

Main Part. Concepts exist together with people and their thoughts. They have the same fluctuations, changes and contradictions as human thoughts. Taking into account different times and different circumstances, they acquire various shades. They can be even opposite. As for the concepts «society», "public» and «social», we can say that they are very popular in science as well as in everyday life. These concepts are used in the economic, legal, political and moral researches. Finally, there is the science of «sociology», which subject is a society. There were numerous definitions of the «society», given by the scientists in the XIX century. The theorists 
defined the society as a plant, an animal, a person, a union, interaction, an attitude, an imitation, a solidarity and a struggle etc. In the XX century, P. Stammler attempted to analyse the society dialectically without any metaphysics. In his opinion: «Social life is an outwardly external regulated social life of people. The external regulation of human behaviour creates an opportunity to understand the social life as a special object» [1]. So, the social is regulated outwardly. There are some controversies in the definition. For example, the society is impossible out of the regulation. So, according to R. Stammler when people live with each other without external influence, we have to understand as the relations, which are out of the society. Following the tradition of C. Thomasius and I. Kant, R. Stammler thinks that the external is legal, whereas the internal deals with the moral. Thus, he considers that the society belongs to the legal sphere. R. Schammler says: "A right is a form of the human society».

E. Spektorskyi, a well-known researcher (lawyer and philosopher) of the early twentieth century in his work "Concept of Society in the Ancient World» proves the idea of the dialectical understanding of the society. Such approach does not solve the scientific, theoretical, cognitive problems. However, it gives the opportunity to develop technologies. In the modern society, we can talk about «information and communication technologies». They influence the functioning of various systems and institutions, whereas they do not explain the object of the study. «If we want to research the society, it means that we recognize the presence of this object in real life. This object should be shown. The concept is alienated from it. Different moral postulates and ideals join it. The complicated concept has been becoming more difficult during the history. However, it can be investigated by the genetic methodology» [2]. Thus, we pay our attention to the problem of the difference between «legality» and «morality» in the context of the organization of the social life as well as the moment of relations: external - internal as the regulators of public administration and «moral consciousness of society».

The term «immunity» as a certain metaphor is quite weighty and meaningful. It traces the mechanisms of the reaction of the individual and social consciousness at the level of behaviour as well as at the so-called «biochemical» one (in addition, it is a medical term). The latter is not plastic. It is rooted in the instinct of self-preservation. So, it becomes subconscious and genetic one. It is found out that the rejection of «unnecessary truth» occurs in the individual and social consciousness at the so-called «before the intellectual stage» of the information perception.

As you know, the immune protection of the body includes two mechanisms: congenital and artificial. The artificial immunization occurs when the body gets the pathogens gradually. Consequently, the vaccine from smallpox, made in childhood, protects the body from this disease during a whole life. Is this «immunization» always therapeutic and positive in the sense of its social significance? Certainly, this is not the answer to the question of the eternal «monsters, generated by the mind». Perhaps this is a little step in attempts to understand the causes of this phenomenon. According to Z. Bauman, the modern "uncertainty day» needs to comprehend the issue of the real forces and the real social and information mechanisms of the «social immunization». How does this process occur? What is the basis of them?

V. I. Svintsov, the doctor of Philological studies, professor, introduces the term «social immunity» in the early 90 of the XX century [3]. His publications and monographs are dedicated to the issue. Numerical explicit and hidden taboos are the important manifestations of the phenomenon of «information immunity». J. Frazer, specialists in religions and beliefs, describe many well-known taboos as well as various rituals, related to them [4]. Similar taboos on knowledge or on information existed in the Soviet Union. They were aimed at the noble intentions to save some ideal, etc. Certainly, the similar taboos can be considered as the symptoms of the social and communicative pathology, a peculiar informational disease of the society. The well-known slogan says «Less Knows, Better Sleep». It is a confirmation of the human rooted fear of the truth that can lead to the mental discomfort, irritation, or a threat to the physical or mental life. Therefore, the «internal censor» of the person gradually formed, which did not allow an undesirable idea, an image to appear.

Does the mechanism of the reaction to «unnecessary» information change in the conditions of the democratization of the society? Does only a 
totalitarian state produce the following protective mechanisms among the marginal? We should recollect that there are explicit and latent taboos in any society. The latter arise operate spontaneously and are oriented on the so-called topical characteristics. From an analytical point of view, the diffuse taboos are also interesting due to the tools, which cover the «immunization». The main one of them is fear.

It is known that the fear is a biologically programmed reaction. A man inherited it from animals. The difference is the possibility of the realizing a sense of the fear. Many of philosophers from Democritus to J.-P. Sartre, tried to analyse the nature of fear. The on the various aspects of this phenomenon of the human existence are variably highlighted artistic and philosophical literature. E. Fromm wrote that a person faced the terrible danger of the turning into the captive of the nature, whereas a human remained free within his/her consciousness. Human self-consciousness makes a person separate from the world. Analysing the reality of the world, the person finds himself out of it. So, everything, lost by the individual, becomes inaccessible and leaves the boundaries of the existing one. R. Descartes called the human ability to separate something, what allocate her/ him freedom. Intellect and doubt exist alongside. The human thought reflected it in R. Descartes's universal doubt and the principles of the modern analytical philosophy. The right to be sceptical of any situation, proclaimed by whoever should belong to the natural rights of the individual. The main idea is in the possibility of doubt, which is often absent in democratic societies.

The determination, by the external pressure or taboo (explicit or latent), creates a system of the social existence within the limits of its own limitations. It is genetically based on a sense of the fear. Nowadays, there are many fears in the modern society. They are natural ones such as a physical survival and the others. For example, we can list up the following fears: the fear of not being recognized, having less material wealth, the fear of being ridiculed, not intelligent, fear of yourself, etc. In this interesting paradox of the dependence on our fears, the power creates the system of the manipulating our consciousness from by the «external regulation». It does not mean only any state authority. We say about another side of the problem such as the power and morality, where we can see the same mechanisms of the dependence on their own fears.

The early psychoanalysis pays a great attention to fear. S. Freud and his followers distinguished two kinds of the fear - rational, determined by the external factors and irrational one. According to the psychoanalysts, anxiety, a feeling of impotence and insignificance generate a depressing mental state that virtually nobody can withstand. In psychoanalyst's opinion, the fear is the result of unfulfilled desires. Nevertheless, these desires can be implemented fictitiously, in the field of our suggestions and hallucinations. The followers of Psychoanalysis believe that human needs are deformed or put in practice in the form of the opposing desires. Thus, there is a reaction to a conflict situation in the human psyche, if the man cannot realize its essence and satisfy the in-depth needs within the society.

Today, there is a replacement the spiritual auto interpretation by a new fictitious one. Fighting against the fears, the human creates the fantasies that help her/him overcome hard experiences. There is also a concept «latent anxiety» in psychology. Sometimes the little feeling of fear caught the person completely. "Information immunity» is a kind of tools to control the latent anxiety, which cannot be dominant the whole time. The phenomenon of «information immunity» is based on the complex conglomerate of the social causes and motives of our behaviour that includes fears, conformism, inertia of thinking, indifference, lack of suffering as well as «informational fatigue», which is natural for the information-oversaturated social communication. Information immunity is formed by the influence of the ideological propaganda as well as the automatically reaction without unnecessary emotions.

Can we consider «informational immunity» as a disease of the society as well as the protective mechanism of the social consciousness? The particularity of this phenomenon is its moral dimension. It does not mean the protection from «information mess», whereas it is the rejection, blocking, concealing the truth, vital information in the context of the moral choice, internal freedom. So we understand ourselves in the dimensions of the present-day material problems as well as the awareness of own appointment and the community as «co-existence of free individuals» without any pathetic. Therefore, it is necessary to revive the genetic needs in the communi- 
cation-cooperation, which creates an atmosphere of trust, the basis for the implementation of free individuals, reduces the degree of the communication-confrontation of the modern world.

The protective reactions of our organism as a whole, and consciousness as a receiver of information, do not exclude the immune tolerance, which is the state of the opposite of the alienation. «Immune tolerance is the recognition of the alien and specific tolerance to it, while the immunity is the recognition of the alien and intolerance to it» [4]. Consequently, the state of tolerance can be necessary for an organism in those situations where biological incompatibility, the rejection reactions turn from protection into a threat to life itself. In modern medicine, special substances are widely used, which suppress the immune rejection reaction - immunosuppressant. Immunosuppressive therapy is aimed at preserving life, in case of the transplantation of internal organs. We can make the similar parallels with social existence.

Conclusions. Finally, in their cultural memory people accumulate the "information of survival», which is being developing independently of their genotype. This information is put into the «repository» of beliefs and ideas. It transforms into the worldview there. The latter characterizes the social system and highlights its true nature and the relation to the well-being of people. The most part of the information, probably $90 \%$ of its total number, is common to all living beings. A small amount of information distinguishes human life from everyone else. The nature of the man is in this small part. The human immune system is a wonderful example of the method of the natural interaction, recognition and development.

Today it is important to understand that the information immunity in the forms of various taboos, implanted «from above», will not be ef- fective. The immune system of the organism as a whole is based on sufficiently effective self-correction of the protective and tolerant reactions. Thus, taking into account the administrative and legal aspects of the protection against such phenomena, we should hope for those protective barriers that are created by the "moral immunity» of the individual. In the certain sense, all the spiritual and moral issues of human existence begin from the point that the development of culture gives the person a right to choose. Its semantic principle are the parts of the universe of spirituality. The functions of control and critical comprehension of the man's moral values are manifested in the following forms of self-consciousness as conscience and shame. At the same time, in the entire system of moral consciousness, the central and fundamental role is the conscience as the internal spiritual understanding of the man's integrity of his life's realization in the context of its fundamental moral assessment.

The desire to build a civilized society is to combine the art of understanding of reality with the ability and desire to finish the works. This idea can be embodied if the community perceives the importance of a similar perspective in the personality development. «The next step in the evolution of mankind requires each individual to become an intellectually developed person, who is capable of creatively and responsibly forming beliefs. They direct the people's actions to meet their reasonable needs, achieve humane goals, high standards of living and objective complete information» [5]. We cannot continue to stay the passive followers of the strangers' ideals. In addition, we cannot be indifferent to the mechanisms of the actions of our nature. Realizing it, we will be able to cure the society and ourselves from the information illnesses, lies, manipulation of the consciousness and all fears.

\section{Список використаних джерел}

1. Нерсесянц В. С. История политических и правовых учений / Под ред. В. С. Нерсесянца. Москва : ИНФРА, 1998. С. 533.

2. Спекторский Е.В. Понятие общества в античном мире. Варшава, 1911. С. 24.

3. Свинцов В.И. Правда, которая не является правдой // Свободная мысль. 1994. № 2.

4. Фрэзер Д. Золотая ветвь: Исследование магии и религии / Пер. с англ. 2-е изд. Москва : Политиздат, 1983. С. 235-251.

5. Петров Р.В. Иммунология. Москва : Медицина, 1986. С. 15-16.

6. Мак Иннис Р. Нравственное начало природы человека; Пер. с англ. В.Я.Васильева. Киев: Б.и., 1999. C. 44. 


\section{References}

1. Nersesyants, V. S. (1998). History of Political and Legal Doctrines. Moscow: INFRA [in Russian].

2. Spectorskyi, E. V. (1911). The Concept of the Society in the Ancient World. Warsaw [in Russian].

3. Svintsov, V. I. (1994). True, Which is not True. Svobodnaya myisl, № 2 [in Russian].

4. Frazer, J. (2nd ed.). (1983). Golden Branch: Study of Magic and Religion. Moscow: Politizdat [in Russian].

5. Petrov, R. V. (1986). Immunology. Moscow : Medicine [in Russian].

6. Mak Innis, R. (1999). Moral Origin of Human Nature.(V. Y. Vasilieva, Trans.). Kyiv: B.I. [in Russian].

УДК 316.77:17.011.1:38

Vasylenko Valeriia,

Information Supply Officer of Vasyl' Stus Donetsk National University v.vasilenko@donnu.edu.ua https://orcid.org/0000-0002-2370-5615

\section{PECULIARITIES OF USING SOCIO-COMMUNICATION TECHNOLOGIES IN THE PROCESS OF DEVELOPING POSITIVE IMAGE OF A HIGHER EDUCATION INSTITUTION}

The purpose of the present article is to define the peculiarities of applying the socio-communicative technologies in the formation of positive image of a higher education institution. The methodology of the research is based on the general scientific and special methods of cognition such us analysis, synthesis, logical method, monitoring and the method of visualization of the research results. The scientific novelty lies in the fact that components of the higher education institution image creation are investigated in the context of their qualitative and quantitative indicators. The peculiarities of applying socio-communication technologies in the process of developing a higher education institution's positive image are determined. In the conclusions the author determines that in the process of developing a unique, emotionally-colored image of an institution of higher education in the consciousness of its target audience, it is necessary to take into account certain peculiarities of using socio-communicational technologies such as the coverage of scientific activity of teachers and students of the HEI, operational updating and provision of information on general issues about educational activity, development and support of social activity of the institution, the opportunity to present a visual demonstration of teacher's pedagogical abilities, advertising and increasing the popularity of the HEI, forming a positive attitude towards the organization of educational process.

Key words: positive image, higher education institution, socio-communicative technologies.

Василенко Валерія Юріївна, спеціаліст з інформаційного забезпечення Донецького національного університету імені Василя Стуса

\section{ОСОБЛИВОСТІ ВИКОРИСТАННЯ СОЦІОКОМУНІКАЦІЙНИХ ТЕХНОЛОГІЙ ПРИ ФОРМУВАННІ ПОЗИТИВНОГО ІМІДЖУ ЗАКЛАДУ ВИЩОЇ ОСВІТИ}

\footnotetext{
Мета дослідження. Визначити особливості використання соціокомунікаційних технологій при формуванні позитивного іміджу закладу вищої освіти. Методологія дослідження базується на застосуванні загальнонаукових та спеціальних методів пізнання, зокрема аналізу, синтезу, логічного методу, моніторингу та методу візуалізаџї результатів дослідження. Наукова новизна. Розглянуто
} 